\title{
A Regulamentação das Leis Incompletas
}

$D_{i z}$ izia-se, há pouco, a propósito de certo projeto de lei oriundo do Executivo, que êste, reivindicando para si a faculdade de dispor em regulamento sôbre a aplicação de determinadas medidas, es* tava tentando invadir a esfera de competência do Legislativo e devia ser contido em suas pretensões.

O episódio sugere alguns comentários que sem êle talvez parecessem ultrapassados.

A preocupação de dar às leis um grau de minúcia tal que as habilite à completa cobertura de tôdas as situaçóes suscetiveis de ocorrerem na prática tem sido fonte de erros da maior gravidade. Jamais a sabedoria, a imaginação e o senso de previsão dos legisladores chegarão à perfeição de conceber e solucionar, antecipadamente, com acêtto, todos os casos e problemas com os quais a lei terá de defrontar-se. Há na vida em sociedade certos imponderáveis rebeldes a qualquer esfôrço de previsão, e certas formas de conflito e harmonia de interêsses, cujos resultados se caracterizam pela impossibilidade de sua acomodação a fórmulas preconcebidas. A lei quanto mais completa pretende ser menos plasticidade apresenta e, portanto, mais dificil se torna ajustá-la às incessantes e por vêzes surpreendentes variações da realidade social.

$E$ É acentuado o descompasso entre a rapidez com que evoluem as sociedades modernas e a lentidão com que se processa a atualização dos textos legais. Para que êsse desajuste seja em parte compensado, o espirito humano concebeu as chamadas leis incompletas, isto é, leis que apenas estabelecem principios e diretrizes gerais, deixando à administração a tarefa de suplementá-las através de regulamentos que lhes possibilitem a conveniente aplicação aos casos individuais.

Ao mesmo tempo que simplificam o processo de elaboração das leis e aliviam as comissốes técnicas do Legislativo de uma considerável carga de trabalho, poupando-lhes tempo e calma para o 
desempenho mais rápido e ordenado de suas atribuições, as leis incompletas ajudam a superar os inconvenientes próprios da instabilidade dos partidos politicos nas suas relações com o poder, e do próprio sistema de recrutamento das assembléias legislativas pelo sufrágio universal.

Hoje soa como imperdoável absurdo a afirmação de que através da elaboração das leis incompletas o Legislativo limita o exercicio de suas prerrogativas constitucionais em favor do Executivo, cujos podêres seriam, assim, acrescidos.

Não há identidade de natureza entre a lei e o regulamento. Êste é subordinado àquela, como instrumento preparatório de sua execução. Ao emiti-lo o Executivo atua na órbitá constitucional que lhe foi demarcada, não podendo fugir ao espirito e à letra da lei a regulamentar. O que se dá é que a complexidade de certas leis impõe uma forma de execução que, embora mais dificil e elaborada, nem por isso adquire natureza peculiar ou transborda da esfera de competência normal do Executivo. Os podêres dêste último não são em verdade acrescidos na regulamentação das leis incompletas, mas apenas utilizados no limite máximo do seu rendimento.

As leis incompletas, na sua exata significação, exprimem umá forma de colaboração entre o Legislativo e o Executivo, mediante a qual o primeiro, no pleno exercicio de suas atribuiçóes de elaborat a lei, recorre aos subsidios que o segundo the pode prestar pelo conhecimento direto, pormenorizado e constante que possui das situações práticas. Mas a citada colaboração, ainda que objetive a realização de uma obra comum, não confere aos colaboradores direitos iguais. $O$ caráter secundário da participáção do Executivo em relação ao Legislativo traduz-se na subordinação do regulamento à lei. 